Tourism 2009, 19/1-2

Włodzimierz Kurek \& Robert Pawlusiński

Department of Tourism and Health Resort Management

Jagiellonian University, Kraków

w.kurek@interia.pl

r.pawlusinski@geo.uj.edu.pl

\title{
INTERNATIONAL TOURISM IN MAŁOPOLSKIE WOJEWÓDZTWO: THE PRESENT SITUATION AND PROSPECTS FOR DEVELOPMENT
}

\begin{abstract}
Małopolskie Województwo is one of the most popular tourist regions in Poland. Due to many attractions, long traditions of hosting tourists and well-developed accommodation facilities, Małopolskie Województwo has become the destination for a growing number of international tourists in recent years. Significant growth in incoming international tourism is found both in Kraków and in mountain areas. The objective of this paper is to present the state of development of incoming international tourism in Małopolskie Województwo.
\end{abstract}

Key words: international tourism, Małopolskie Województwo, tourism in Małopolska.

\section{INTRODUCTION}

From the beginning of the 1990's Małopolskie Województwo has welcomed a great proportion of the international tourists coming to Poland. Due to its many attractions, including the international importance of Kraków as a European culture capital as well as the well-developed tourism infrastructure, the region has become one of the most visited in Poland. A distinct growth of incoming international tourism is observed both in Kraków and in mountain areas.

The aim of this article is to present the state of international tourism in Małopolskie Województwo from the moment Poland joined the European Union until now. Various source materials have been used such as Central Statistical Office data, reports of the Institute of Tourism, spatial planning documentation on tourism in Małopolska, and the results of tourism research in Małopolskie Województwo commissioned by the marshal of the Województwo and conducted on a regular basis since 2003 .

\section{CONDITIONS FOR INTERNATIONAL TOURISM DEVELOPMENT}

The attractiveness of Małopolskie Województwo for international tourism is based on culture, among which the sites of UNESCO's World Cultural and
Natural Heritage List are of special importance. Out of eleven historical sites on the UNESCO list in Poland, as many as five are located here: Kraków's historic and planned architectural centre, Wieliczka salt mines, the Nazi concentration and extermination camp (Auschwitz-Birkenau) in Oświęcim, the monasticpilgrimage site in Kalwaria Zebrzydowska, and the wooden churches in Binarowa, Dębno, Lipnica Murowana and Sękowa.

The greatest attraction in the region is Kraków the main economic and academic centre of Małopolska, a city with a rich historic heritage regarded now as the centre of Polish cultural and religious life. In total, there are 1100 architectural sites on the Kraków register of monuments located mainly on Wawel Hill and within the Old Town, as well as in Kazimierz and Stradom. Due to its unique historical value, the entire area was entered on the UNESCO World Heritage List in 1978. The historical part of Nowa Huta - the first Polish socialist city built in the 1950's near Kraków (now a district of the city) - also has architectural rank.

Beside the numerous historical buildings, the following factors contribute to Kraków's international importance for tourism (KUREK \& FARACIK 2008, PAWLUSIŃSKI 2007):

- a rich cultural offer, including many events of international rank (such as the Sacrum-Profanum Festival, Jewish Culture Festival) and traditions and 
folk customs still alive (such as the Lajkonik festival and Emaus church fair);

- numerous cultural institutions (such as the Kraków Philharmonic Hall, the Kraków Opera House);

- prominent cultural personages and academia connected with Kraków, including Karol Wojtyła Pope John Paul II, as well as Nobel Prize winners (Miłosz and Szymborska) and famous artists and creators of culture (such as Penderecki);

- status as one of the most important academic centres in Poland with traditions going back to the $14^{\text {th }}$ c.;

- the site of religious catholic cults of international importance (Sanctuary of Divine Mercy in Łagiewniki, Wawel Cathedral);

- the cultural and religious heritage of the former Jewish population, located mainly in Kazimierz and Podgórze districts.

Apart from Kraków, potential for international tourism is also present in Wieliczka and Oświęcim, as well as in Biecz, Stary Sącz, Nowy Sącz, Tarnów and Olkusz, where historical architectural complexes remain. Mediaeval castles and ruins are attractive for tourists, for example those in the area of KrakówCzęstochowa Jurassic Highlands (Ojców, Pieskowa Skała, Tenczyn, Wygiełzów), in the Pieniny Mountains (Czorsztyn, Niedzica), as well as in Dębno near Brzesko, Niepołomice, Nowy Wiśnicz and Sucha Beskidzka (GAŚ, KIDOŃ \& ROTTER 2000-1). protected as national parks and within Małopolskie Województwo there are five (Babia Gora, Gorce, Magura, Pieniny, Tatra) - two have the status of international biosphere reserves (Babia Góra and Tatra) - and one with an upland landscape (Ojców).

Mountainous areas are suitable for various forms of 'specialised' tourism. There are more than 3,400 $\mathrm{kms}$ of marked tourist trails for mountain hiking in the most attractive areas of the mountain ranges in Małopolska (Turystyka... 2008). Bicycle and horse riding trails are also relatively well-developed, but many are local. An important form of active leisure in winter is down-hill skiing. The best conditions can be found in the Tatra Mountains and in the higher parts of the Beskidy Mountains. In Małopolskie Województwo, there are more than 80 skiing resorts administering more than 250 ski runs in total. The main winter sports resort in Małopolska is Zakopane while nearby new centres in Bukowina and Białka Tatrzańska have been developed. Furthermore, there are centres in Beskid Sądecki (Krynica, Wiechomla), in the Pieniny, Gorce and Beskid Żywiecki mountains.

An important factor enabling the potential for international tourism development is the system of accommodation facilities. Małopolskie Województwo leads concerning their number as well as beds in Poland. In 2008, according to the Central Statistical Office, accommodation facilities included 843 establishments with a total of 64,100 beds (Table 1 ).

T a b l e 1. Accommodation capacity in Małopolskie Województwo: 2003-7

\begin{tabular}{|c|c|c|c|c|c|c|}
\hline & 2003 & 2004 & 2005 & 2006 & 2007 & $\begin{array}{l}\text { Change } \\
\text { 2003-7 }\end{array}$ \\
\hline $\begin{array}{l}\text { The number of accommodation establishments } \\
\text { hotels }\end{array}$ & $\begin{array}{l}878 \\
136\end{array}$ & $\begin{array}{l}873 \\
154\end{array}$ & $\begin{array}{l}825 \\
152\end{array}$ & $\begin{array}{l}819 \\
158\end{array}$ & $\begin{array}{l}843 \\
180\end{array}$ & $\begin{array}{l}-4.1 \% \\
32.4 \%\end{array}$ \\
\hline $\begin{array}{l}\text { The number of beds } \\
\text { in hotels }\end{array}$ & $\begin{array}{l}65,074 \\
14,799\end{array}$ & $\begin{array}{l}65,256 \\
16,187\end{array}$ & $\begin{array}{l}61,509 \\
15,609\end{array}$ & $\begin{array}{l}62,747 \\
17,245\end{array}$ & $\begin{array}{l}64,127 \\
20,425\end{array}$ & $\begin{array}{l}-1.5 \% \\
38.1 \%\end{array}$ \\
\hline
\end{tabular}

S o u r c e: based on Central Statistical Office data

Wooden architectural monuments are of international class, confirmed by the entry of the most precious on the UNESCO Heritage List in 2003 (i.e. Binarowa, Dębno, Lipnica Murowana, Sękowa).

Beside culture, natural resources play an important role for international tourism development enabling cognitive tourism development on the one hand and on the other with the potential for several forms of active leisure. Małopolskie Województwo is distinguished by the richness and diversity of its natural environment. In the southern part, there are mountain ranges including the Tatras, the highest in Poland while upland landscapes dominate in the northern part. The most valuable natural areas are
Most are available all year round (87.3\%).

Among accommodation facilities, the dominant part consists of traditional hotels (hotels, motels, guest-houses) - 286 establishments forming 33.9\% of the total with 35,800 beds. This accommodation type is essential in the reception of international incoming tourism with more than 58\% choosing this type (Badanie ruchu... 2007). It should be emphasized that traditional hotel accommodation has been the most dynamically developing sector in recent years, with regard to both quantity and quality. This especially concerns hotels, the number of which grew in 2003-7 by $32.4 \%$ and most were opened in Kraków (30) of relatively high standard. At present, there are seven 
five-star hotels and seventeen four-star in Małopolskie Województwo.

An important group consists of those facilities prepared for youth tourism, such as hostels, which offer similar services and standards to mountain lodges. In Kraków alone there were more than 80 known as 'hostels' in 2007. Their dynamic development has been caused on the one hand, by the global fashion for hostel accommodation, especially among the young, on the other by the relatively low investment and fast financial rate of return of invested capital (KUREK \& FARACIK 2007).

In terms of spatial distribution, mountain areas dominate with $68.4 \%$ of establishments and $60.8 \%$ of beds. The most developed are in the powiats of Nowy Sącz, Tatra and Nowy Targ with around 50\% of the total. Another area of high concentration is Kraków with 157 establishments including most of the hotels with 19,400 beds.

An improvement in accessibility of Małopolska region, especially by air, has played an important role for international tourism development. Małopolska can be reached from four international airports (Kraków Balice, Katowice Pyrzowice, Rzeszów Jasionka and Poprad Tatry in Slovakia), among which Balice and Pyrzowice are of the greatest importance.

The International Airport Kraków Balice is the second biggest in Poland (three million passengers in 2007). Development began in 2004 when the low-cost carriers entered the Polish market and at present, the airport offers regular connections to 53 cities, including 49 in Europe and three outside (Chicago, New York, Tel Aviv). The flights are managed by fifteen carriers, among whom are Easy-Jet (23.7\%), Ryanair (19.3\%), LOT (12.3\%), Lufthansa (7.7\%) and Norwegian. Katowice-Pyrzowice airport plays an important role (two million passengers in 2007) as a result of the short distance from Pyrzowice to Kraków (complementing the offer of Balice airport) and the marketing practice of the main carrier WizzAir who promote Pyrzowice as the airport for Kraków. At the moment, there are 28 connections to European cities managed mainly by the Hungarian carrier WizzAir which covers more than 65\% of passenger transportation. It is worth mentioning that both airports have been significantly modernised and enlarged in recent years, for example new terminals have been created and their accessibility improved. Such investment will be continued in the coming years.

\section{TOURISM}

Małopolskie Województwo is one of the most visited by international tourists in Poland. According to the
Institute of Tourism, concerning figures for 2007, it is third with $7.8 \%$ after Mazowieckie and Wielkopolskie Województwos. It has to be emphasized as well that Małopolskie region receives the highest percentage of international tourists coming to Poland for sightseeing and leisure purposes. This importance is even greater if we consider data from the Central Statistical Office on tourists who choose 'registered' accommodation facilities. According to its data, in 2007 the Małopolska region received the highest number of international tourists in Poland, as much as $22.3 \%$.

This development has been observed since the moment Poland joined the European Union. In 2003, it was visited by $1.3 \mathrm{mln}$ and in 2004 , after joining the European Union, 2,1 mln, i.e. 62\% more. This trend has continued, although the rate of growth is not so high. Between 2003 and 2007 a nearly two and half fold increase was observed (Table 2). At present, around 3.3. mln visit among which $2.2 \mathrm{mln}$ stay for more than one night. In the total number of tourists this amounts to $25 \%$.

$\mathrm{T}$ a b l e 2. International tourists coming to Małopolskie Województwo: 2003-7

\begin{tabular}{|l|c|c|c|c|c|c|}
\hline & 2003 & 2004 & 2005 & 2006 & 2007 & $\begin{array}{c}\text { Change } \\
\text { 2003-7 }\end{array}$ \\
\cline { 2 - 7 } & 1,325 & 2,071 & 2,365 & 2,871 & 3,266 & $246.5 \%$ \\
\hline $\begin{array}{l}\text { Visitors } \\
\text { in total } \\
\text { tourists }\end{array}$ & 1,210 & 1,720 & 1,950 & 2,160 & 2,200 & $181.8 \%$ \\
\hline $\begin{array}{l}\text { Visitors } \\
\text { choosing } \\
\text { 're- } \\
\text { gistered' } \\
\text { accom- } \\
\text { modation } \\
\text { facilities }\end{array}$ & 555.5 & 725.4 & 889.4 & 933.7 & 979.2 & $176.9 \%$ \\
\hline
\end{tabular}

S o u r c e: based on data from the Central Statistical Office and the Institute of Tourism.

In 2007, there were 979,200 tourists in 'registered' accommodation facilities, with a total of $2.3 \mathrm{mln}$ 'accommodation services' sold. Visitors are visibly dominated by citizens of European Union countries who constitute more than two thirds, with most from the United Kingdom (17.1\%), Germany (11.1\%), Italy $(6.8 \%)$ and France $(5.3 \%)$. These four countries covered $40.4 \%$ of the total. In 2003-7, a very high increase in visitor numbers from EU countries was noticeable (Table 3); especially from Ireland (more than tenfold increase) and the United Kingdom (fourfold). This is connected to the expansion of flights from Balice airport. 
An increase has been noted also in visitors from Russia and Ukraine, and in 2004 regulations on visafree visits from these countries ceased to be enforced, in 2007, citizens of Russia and Ukraine constituted about $8 \%$ of total tourists. Numbers from Slovakia and Czech Republic are relatively insignificant with the percentage from those two countries only $2.5 \%$.

Tourists from outside Europe make up nearly $20 \%$ of all visitors. In this group, the greatest proportion are from the United States and Israel (together around $50 \%$ of all non-European visitors). Figures from Japan $(10,400)$ and Canada $(7,800)$ are much lower.

Most tourists are visiting the area for the first time (57\%). An average visit is 4-5 days and it is highly diversified. The shortest are from citizens of Austria, Czech Republic and Slovakia - on average three days while those from Spain, Russia, Ukraine and Italy stay much longer: Spain - 7.7 days, Russia, Ukraine and Italy - more than 5 days. Incoming tourism is characterized by distinct seasonality, with most visits between May and September. In winter, only the number of Ukrainian and Russian visits noticeably increases. The relatively high percentage coming by air (so-called 'city breaks') are mainly for weekend stays.

$\mathrm{T}$ a b l e 3 . International tourists by country of origin

\begin{tabular}{|l|r|r|r|r|r|r|}
\hline \multirow{2}{*}{$\begin{array}{l}\text { Country } \\
\text { of origin }\end{array}$} & \multicolumn{5}{|c|}{ in thousands } & \multicolumn{1}{c|}{$\begin{array}{c}\text { Change } \\
2003-7 \\
\%\end{array}$} \\
\cline { 2 - 6 } $\begin{array}{l}\text { Great } \\
\text { Britain }\end{array}$ & 41,7 & 67,4 & 106,4 & 140,6 & 167,7 & 401.7 \\
\hline Germany & 83,7 & 109,0 & 137,4 & 123,9 & 108,7 & 129.9 \\
\hline $\begin{array}{l}\text { United } \\
\text { States }\end{array}$ & 50,6 & 74,1 & 77,1 & 80,2 & 68,8 & 136.0 \\
\hline Italy & 40,0 & 53,2 & 67,6 & 67,2 & 67,0 & 167.4 \\
\hline France & 34,5 & 45,1 & 57,2 & 48,8 & 51,6 & 149.4 \\
\hline Ukraine & 26,3 & 25,7 & 30,8 & 41,0 & 50,3 & 191.4 \\
\hline Norway & 24,3 & 26,7 & 30,7 & 40,3 & 42,7 & 175.8 \\
\hline Israel & 26,6 & 29,5 & 38,2 & 36,6 & 40,2 & 151.0 \\
\hline Spain & 14,8 & 23,1 & 30,7 & 30,1 & 32,0 & 216.8 \\
\hline Russia & 12,2 & 14,6 & 18,7 & 24,3 & 29,1 & 238.3 \\
\hline Ireland & 2,8 & 5,4 & 9,6 & 19,1 & 29,1 & 1049.8 \\
\hline Hungary & 19,0 & 25,5 & 29,1 & 26,2 & 28,5 & 150.1 \\
\hline $\begin{array}{l}\text { Switzer- } \\
\text { land }\end{array}$ & 16,2 & 16,1 & 18,5 & 18,6 & 22,5 & 139.0 \\
\hline $\begin{array}{l}\text { Nether- } \\
\text { lands }\end{array}$ & 14,1 & 18,5 & 24,0 & 22,1 & 19,2 & 135.8 \\
\hline Belgium & 9,5 & 13,0 & 15,3 & 15,0 & 17,2 & 181.4 \\
\hline $\begin{array}{l}\text { Other } \\
\text { countries }\end{array}$ & 137,4 & 178,5 & 198,3 & 201,1 & 204,9 & 49.1 \\
\hline
\end{tabular}

S o u r c e: based on data from the Regional Statistical Office Kraków.

The motivation of visitors is complex. According to Institute of Tourism research from 2008, most international tourists declare more than one reason
(Badanie ruchu ... 2008). In most years, the most important motivation has been strictly tourist such as sightseeing, as well as recreation and leisure in a broader sense as declared by more than $60 \%$ of international tourists. Next are visiting relatives and friends $(26 \%)$, entertainment $(17 \%)$ and mountain hiking (13.5\%). Nearly $10 \%$ of visitors rank shopping among the main reasons, especially those from Slovakia who travel for trade purposes to borderland towns with markets in Małopolska, especially to Nowy Targ and Jabłonka. About 7\% international visitors come to Małopolska for religious reasons while a similar percentage come for health and business purposes.

In terms of spatial distribution, Kraków dominates. In 2007, 820,000 international tourists stayed here, as much as $83.7 \%$. In recent years, gminas surrounding the city have played an important role, and in 2007, Kraków and its neighbouring communes together attracted more than $85 \%$.

T a b l e 4. International tourists coming to Kraków: 2003-7

\begin{tabular}{|l|c|c|c|c|c|c|}
\hline & 2003 & 2004 & 2005 & 2006 & 2007 & $\begin{array}{l}\text { Change } \\
2003-7\end{array}$ \\
\cline { 2 - 7 } & \multicolumn{7}{|c|}{ in thousands } \\
\hline $\begin{array}{l}\text { Visitors } \\
\text { in total }\end{array}$ & 978 & 1,650 & 1,788 & 2,121 & 2,492 & $254.6 \%$ \\
tourists & 880 & 1,320 & 1,430 & 1,485 & 1,620 & $184.1 \%$ \\
\hline $\begin{array}{l}\text { Visitors } \\
\text { choosing } \\
\text { 're- } \\
\text { gistered' } \\
\text { accom- } \\
\text { modation } \\
\text { facilities }\end{array}$ & 436.9 & 591.5 & 731.8 & 770.8 & 820.0 & $187.7 \%$ \\
\hline
\end{tabular}

S o u r c e: based on data from the Central Statistical Office and the Institute of Tourism.

According to tourist research commissioned by the Województwo authorities, about $2.5 \mathrm{mln}$ visit Kraków (Table 4), and $1.6 \mathrm{mln}$ stay in the city for more than one night (Badanie ruchu... 2007). Sightseeing, leisure in the broader sense, and entertainment lead while the importance of other motivations such as participation in the cultural, academic and economic life of the city (congresses, conferences and seminars) is also increasing. The variety of nationalities reflects that of the entire Województwo. It is worth noticing that a relatively large group consider Kraków the main, often the only, destination. On average, more than $80 \%$ stay only here, mostly from Ireland (92.4\%), Spain (92\%), and Italy (91\%), as well as Great Britain and Norway (each around $90 \%)$. This indicator has lower values for Germany (75.7\%), Hungary (66.9\%), Slovakia (65.8\%), Czech Republic (65.1\%), Russia (60.4\%) and Ukraine 
(52.4\%). The high percentage staying in Kraków overnight indicates the important role of this city as a centre for international tourism.

Zakopane is an important tourist resort. In surveys, it is one of the most significant centres and according to the Central Statistical Office, in 2007 there were 62,700 tourists in Zakopane, with a total 182,600 accommodation services sold. The percentage of international tourists in the total number coming to Zakopane, is $16.7 \%$ attracted due to the natural value of the Tatra Mountains and its winter sports offer. Highlander culture and participation in various sport and recreation events, and most importantly the International Ski Jumping Cup organized in midJanuary, are also very popular.

Oświęcim and Wieliczka are of great importance for international tourism, however both are dominated by one-day tourism. In 2007, the Memorial and Auschwitz-Birkenau Museum was visited by around 755,000 international tourists. The highest - by number - are from the United Kingdom $(104,000)$, United States $(90,900)$, Germany $(60,200)$, Italy $(56,600)$, Israel $(44,000)$, France $(42,600)$, South Korea $(37,900)$ and Norway (36,800). Only 12,800 visitors stayed overnight in Oświęcim, which is only $1.7 \%$ of the total.

The main purpose of visiting Wieliczka is to see the historical Salt Mine, entered on the UNESCO Heritage List in 1978, one of the first Polish sites. In 2007, the mine was visited by 1.16 mln tourists, of which $58 \%$ were international. The highest number came from the United Kingdom (85,500), United States (44,800), Germany $(44,100)$, Italy $(43,700)$, France $(40,600)$, Russia, South Korea, Norway and Spain - which together constituted more than 50\%. Accommodation was used by only 9,200 foreigners who bought 13,900 beds. Other tourist resorts in the Małopolska region with high figures are Tarnów $(9,500)$, Krynica Zdrój $(4,800)$, Nowy Sącz $(3,400)$ and Kalwaria Zebrzydowska $(3,200)$.

International pilgrimage tourism in Małopolska is concentrated in three centres: Kraków-Łagiewniki, Kalwaria Zebrzydowska and Wadowice. The Sanctuary of Divine Mercy in Łagiewniki is one of the relatively new pilgrimage destinations with its beginnings dating back only to the end of the 1960's and the cult developed further in the 1990's due to the beatification of Saint Faustina. Despite the short time of the sanctuary's functioning, it has become an international pilgrimage centre. Pilgrimage tourism at this site is estimated at more than two million per year, of which about $25 \%$ come from abroad dominated by pilgrims from Europe, mainly Slovaks (about 20\% of international pilgrims), Germans (13\%) and Czechs $(7 \%)$. The greatest number of pilgrims from nonEuropean countries come from the United States (JACKOWSKI \& SOŁJAN n.d.).
The calvary sanctuary in Kalwaria Zebrzydowska has longer pilgrimage traditions dating back to the $17^{\text {th }}$ c. The Kalwaria sanctuary has been popularized at an international level by papal visits in 1979, 2002 (John Paul II), 2006 (Benedict XVI) and by the site being entered on the UNESCO heritage list in 1999. At present, around $1.5 \mathrm{mln}$ pilgrims are recorded annually at the sanctuary. The percentage of international pilgrims is relatively low, around 20,000, although distinctly growing. Most come from Slovakia, Italy, Germany, Hungary, England, France, Ukraine and the United States.

International pilgrimage tourism development is also to a great extent bound up with Karol Wojtyła Pope John Paul II. Apart from Kraków and Kalwaria Zebrzydowska, the pilgrimage route 'In the Footsteps of John Paul II' leads to Wadowice - the town where the Pope was born and where he spent his youth - and the basilica and his family house. On average, around 400,000 come to Wadowice, 50,000 from abroad. The greatest so far was in 2005 when Pope John Paul II passed away. The largest groups of international tourists are Italians (20\%) and Germans $(10 \%)$ with the US (9\%), Slovakia (7\%), France $(6 \%)$, Spain (6\%) and Hungary (4\%) (MRÓz 2007).

Pilgrimages are characterised by strong seasonality. Numbers are high on religious holy days, as well as on church festivals. In order to meet the needs of pilgrims, accommodation facilities and a tourism infrastructure develop around the sanctuaries. A relatively good infrastructure can be found in Kalwaria Zebrzydowska and with the enlargement of the John Paul II Centre 'Be not afraid!', the tourist service for pilgrims in Łagiewniki will improve significantly.

\section{DEVELOPMENT PROSPECTS}

The dynamic development of international tourism in Małopolskie Województwo results from favourable internal and external conditions. It has competently used the international economic prosperity to strengthen its image on the international tourism market while changes in the tourism potential of the Województwo have also contributed to this process, for example the significant quantitative and qualitative development of accommodation facilities as well as improvements in accessibility to the region. However, there is still a barrier hampering the development: the distinct disproportion between Kraków and the rest of the region in standards and service quality. Another issue is the poor condition of road networks and the nearly complete absence of high quality road. So prospects for international tourism development in Małopolska strongly depend 
on an improvement in tourism infrastructure and road accessibility to the 'interior' of the region. European Union funds are expected to enable the implementation of these tasks. A competent allocation of those funds can significantly increase the competitiveness of Małopolska on the international tourism market. Local government should play an essential role here, because as the actual managers of the area, they have the broadest perspective and they can identify local needs most accurately.

The Małopolska region is still not a fully developed tourism area in terms of international tourism. Most such tourists come to this region for the first time and mostly limited to Kraków. Beside the capital, international tourism is relatively insignificant and has virtually no affect on the social and economic structure of the area. In order to improve this situation, intense marketing campaigns are required, aiming at the lengthening of international tourist visits time as well as spreading the areas visited. Małopolska's tourism policy, as observed in recent years, has aimed at promotion of the cultural value of Kraków, but it could result in negative effects in the future. This is because modern tourism demand is highly inconsistent and tourists are constantly looking for new experiences and new sites to visit. Another influence could be the accession of new EU member states (Rumania and Bulgaria), which could divert tourist's attention from Poland and discount the improvement of its international image.

In the tourism development programme for 200813 the future development of tourism in Małopolska should concentrate on the creation of branded products, such as 1) city, cultural and pilgrimage tourism, 2) active, recreational and specialised tourism, 3) health resort and health promotion tourism, 4) tourism in rural areas, 5) business tourism, and 6) transit and borderland tourism (Kierunki rozwoju... 2008). The direction for tourism development established at Województwo level seem to be relevant and make use of the entire tourism potential in the region and implementation of these guidelines can significantly increase the attractiveness of Małopolska for tourists. However, it should be noted, that not all of the products chosen in Małopolska will play an important role for the development of international incoming tourism. This is due to the competitive tourist offer from Slovakia, for example ski tourism or health resort tourism. With regard to international tourism, from all products mentioned, the most important are city and cultural tourism, active tourism, pilgrimage tourism and business tourism.
An important objective of regional tourism policy in the coming years will be the extension of Balice airport. The present facility, despite its enlargement, does not meet standards and further exploitation would exceed its maximum capacity. Apart from expansion of the terminals, last year's investments accommodation facilities and parking spaces - will contribute to the increasing importance of the airport for tourism reception. In the vicinity of the airport, there will be a four-star hotel with conference facilities and multi-storey garaging for nearly 1000 cars. The absence of a strategic carrier is also hampering the development of air tourism. After the withdrawal of their services by Sky Europe and Centralwings, no other airline has decided to establish its base in Kraków which resulted in losing many connections and in shrinking of the spatial range of flights. This situation, if it persists, can significantly affect international tourism rates.

\section{BIBLIOGRAPHY}

Badanie ruchu turystycznego w województwie małopolskim 2008. Raport końcowy, 2008, Instytut Turystyki, Warsaw.

Badanie ruchu turystycznego w województwie małopolskim. Raport końcowy, 2007, Ipsos, Warsaw.

Badanie ruchu turystycznego w Małopolsce w 2006 r. Skrót raportu końcowego, Małopolska Organizacja Turystyczna, Kraków.

BARTOSZEWICZ W., SKALSKA T., 2008, Zagraniczna turystyka przyjazdowa do Polski w 2007 roku, Instytut Turystyki, Warsaw.

GAŚ M., KIDOŃ E, ROTTER K., 2000-2001, Województwo małopolskie turystyka, Folia Geographica, Series Geographica-Oeconomica, vol. XXXI-XXXII, pp. 179-206.

JACKOWSKI A., SOŁJAN I. b.d., Łagiewniki jako ośrodek pielgrzymkowy - article on Internet site of Kraków Archidiocese - http:// diecezja.pl/ (download on 15th January 2009).

Kierunki rozwoju turystyki dla województwa małopolskiego na lata 20082013, 2008, Urząd Marszałkowski Województwa Małopolskiego, Kraków.

KUREK W., FARACIK R., 2008, Wybrane problemy rozwoju turystyki w Krakówie u progu XXI w., Turyzm, t. 1, z. 1, pp. 65-82.

KUREK W. (ed.), 2007, Turystyka, Wyd. Nauk. PWN, Warsaw.

MrÓZ F., 2007, "Tu w tym mieście, w Wadowicach wszystko się zaczęto...". Pielgrzymowanie i turystyka religijna do miasta rodzinnego Karola Wojtyty, Peregrinus Cracoviensis, z. 18, p. 77-98.

PAWLUSIŃSKI R., 2007, Wydarzenia kulturalne a rozwój turystyki $w$ Krakowie, [in:] A. Stasiak (ed.) Kultura i turystyka. Razem czy oddzielnie?, Wyd. WSTiH w Łodzi, Łódź, pp. 219-236.

Ruch turystyczny w Krakówie w 2007 r. Raport z badań, 2007, Ipsos, Warsaw.

Turystyka w województwie małopolskim w 2007 r., 2008, Informacje i Opracowania Statystyczne, US w Krakowie, Kraków. 